JURNAL RISET MAHASISWA AKUNTANSI

http://ejournal.unikama.ac.id/index.php/jrma

JRMA, Volume 6, No 1, April 2018

\title{
ANALISIS KINERJA APBD DENGAN PENGUKURAN VALUE FOR MONEY PEMERINTAH KOTA MALANG (TAHUN PERIODE 2011-2015)
}

\author{
Evi Indana Ulfa \\ e-mail: eviindana@yahoo.com \\ Anwar Made \\ Eris Dianawati \\ (Program Studi Akuntansi, Fakultas Ekonomika dan Bisnis Universitas Kanjuruhan \\ Malang)
}

\begin{abstract}
ABSTRAK
Penelitian ini bertujuan untuk menganalisis untuk mengetahui bagaimana mengukur efektivitas APBD Pemerintah Kota Malang, untuk mengetahui apakah cukup efektif APBD Pemerintah Kota Malang dan untuk mengetahui bagaimana mengukur efektifitas akuntansi Pemerintah Kota Malang. Penelitian ini menggunakan metode penelitian kuantitatif. Data yang digunakan didalam penelitian ini adalah data sekunder, yaitu data yang telah ada dari dokumen resmi pemerintah daerah kota Malang. Teknik pengumpulan data yang dilakukan peneliti adalah dengan cara Logging data. Hasil penelitian Tingkat efektivitas APBD Pemkot Malang tahun 2011 - 2015 sangat efektif, karena rata-ratanya sebesar 103,27 persen, lebih besar dari kriteria yang ditentukan, yaitu minimal 90 persen, tingkat efisiensi APBD Pemkot Malang tahun 2011 - 2015 kurang efisien, karena rata-ratanya sebesar 105,26 persen lebih besar dari kriteria yang ditentukan, yaitu maksimal 80 persen, bila ditinjau dari seberapa besar proporsi PAD dapat memberikan kontribusi terhadap pendapatan daerah, tingkat kemampuan keuangan daerah Pemkot Malang tahun 2011 - 2015 kurang mampu, karena rata-ratanya 13,03 persen jauh lebih kecil dari kriteria yang ditentukan, yaitu minimal 40 persen dan bila ditinjau dari seberapa besar PAD dapat menopang belanja daerah, tingkat kemampuan keuangan daerah Pemkot Malang tahun 2011 - 2015 kurang mampu, karena rata-ratanya sebesar 12,17 persen lebih kecil dari kriteria yang ditentukan, yaitu minimal 40 persen.
\end{abstract}

Kata kunci: $A P B D$ Pemerintah, efektivitas, efisiensi

\section{ABSTRACT}

This study aims to analyze to find out how to measure the effectiveness of the Malang City's APBD (Local Government Budget), to find out whether the Malang City's APBD (Local Government Budget) is quite effective and to find out how to measure the Malang City Government's accounting effectiveness. This research uses quantitative research methods. The data used in this study are secondary data, that is data already available from official documents of the Malang city government. Data collection techniques used by researchers is by logging data. Results of research The effectiveness level of Malang City's APBD (Local Government Budget) in 2011-2015 was very effective, because the average was 103.27 percent, greater than the specified criteria, which is at least 90 percent, the level of efficiency of the Malang City's APBD (Local Government Budget) in 2011-2015 was less efficient, because it was average -The rate of 105.26 percent is greater than the specified criteria, which is a maximum of 80 percent, when viewed from how much the proportion of $P A D$ can contribute to regional income, the level of financial capability of the Malang City Government in 2011-2015 is less able, because on average 13.03 
percent is far less than the specified criteria, which is a minimum of 40 percent and when viewed from how much PAD can sustain regional spending, the level of financial capability of Malang City Government in 2011 - 2015 is less able, because the average is 12.17 percent smaller than the specified criteria, which is a minimum of 40 percent

Keynotes: Local Government Budget, effectiveness, efficiency

\section{PENDAHULUAN}

Untuk menjamin dilakukannya pertanggungjawaban publik oleh lembagalembaga pemerintah maka diperlukan perluasan sistem pemeriksaan, tidak sekedar conventional, namun perlu juga dilakukan value for money (VEM). Dalam pemeriksaan yang konvensional lingkup pemeriksaan terhadap keuangan dan kepatuhan (financial and compliance), sedangkan dalam pendekatan baru ini selain audit keuangan dan kepatuhan juga perlu dilakukan kinerja (perfomance). Performance meliputi audit ekonomi, efisiensi dan efektivitas. Ekonomi dan efisiensi disebut management, sedangkan efektivitas disebut program, Istilah lain untuk performance tersebut adalah VFM atau disingkat $3 E^{\prime} s$ (economy, efficiency and effectiveness).

Disamping itu pemerintah daerah dituntut untuk berupaya meningkatkan sumber Pendapatan Asli Daerah (PAD) agar mampu membiayai penyelenggaraan pemerintah dan lebih meningkatkan pelayanan kepada masyarakat. Salah satu faktor yang harus dipersiapkan adalah kemampuan pengelolaan keuangan daerah.

Pengelolaan keuangan daerah sangat besar pengaruhnya terhadap nasib suatu daerah karena daerah dapat menjadi daerah yang kuat dan berkuasa serta mampu mengembangkan potensi daerahnya atau menjadi daerah tertinggal. Pengelolaan daerah yang dilakukan secara ekonomis, efisien, efektif, transparansi, akuntabilitas dan berkeadilan akan mendorong pertumbuhan ekonomi. Untuk pengelolaan daerah tidak hanya dibutuhkan sumber daya manusia, tetapi juga sumber daya ekonomi berupa keuangan yang dituangkan dalam suatu Anggaran Pendapatan dan Belanja Daerah (APBD).

Untuk mengetahui sampai seberapa baik kinerja keuangan Pemkot Malang, maka perlu dilakukan analisis terhadap APBD-nya. Halim dan Nasir (2006) dalam penelitiannya menyimpulkan bahwa: (1) kemampuan keuangan daerah dalam menopang belanja daerah rata-rata sebesar 15,51 persen, sisanya sebesar 84,49 persen bergantung pada sumber keuangan di luar PAD (dana perimbangan dan lain-lain pendapatan daerah yang sah, (2) pertumbuhan PAD dari tahun ke tahun menunjukkan penurunan.

\section{TINJAUAN PUSTAKA}

\section{Penyusunan APBD}

Berdasarkan pasal 18 UUD 45 Amandamen IV, tujuan pembentukan Daerah Otonom adalah untuk meningkatkan daya guna penyelenggaraan pemerintahan guna melayani masyarakat dan melaksanakan program pem-bangunan. Dalam rangka penyelenggaraan daerah otonom, menurut penjelasan pasal 64 UU No. 5 Tahun 1974, fungsi penyusunan APBD menurut Bastian (2010:48) penyusunan APBD haruslah diletakkan dalam kerangka perencanaan pembangunan yang mempertimbangkan skala prioritas pembangunan. Selanjutnya, pelaksanaan APBD haruslah dikendalikan menurut sasaransasaran yang jelas dan terukur. 


\section{Prinsip-Prinsip Pengelolaan Keuangan Daerah}

Prinsip-prinsip pengelolaan keuangan daerah menurut Mardiasmo (2002:29-30) meliputi: akuntabilitas, value for money, kejujuran, transparansi, pengendalian dan kuntabilitas.

\section{Pokok-pokok Kebijakan Penyusunan APBD}

Menurut Permendagri nomor 32 Tahun 2008, pokok-pokok kebijakan yang perlu mendapat perhatian pemerintah daerah dalam penyusunan APBD terkait dengan kebijakan pendapatan daerah, kebijakan belanja daerah serta kebijakan penerimaan pembiayaan dan pengeluaran pembiayaan daerah, sebagai berikut:

\section{Pendapatan Daerah}

Pendapatan Asli Daerah (PAD)

Dalam merencanakan target PAD supaya mempertimbangkan realisasi penerimaan tahun lalu, potensi, dan asumsi pertumbuhan ekonomi yang dapat mempengaruhi masing-masing jenis penerimaan daerah, dalam upaya peningkatan PAD, agar tidak menetapkan kebijakan yang memberatkan dunia usaha dan masyarakat, dalam menganggarkan rencana pendapatan daerah dari hasil pengelolaan kekayaan daerah yang dipisahkan, hendaknya rasional dibandingkan dengan nilai kekayaan daerah yang disertakan, serta memperhatikan fungsi penyertaan modal tersebut.

Komisi, rabat, potongan atau penerimaan lain dengan nama dan dalam bentuk apapun yang dapat dinilai dengan uang sebagai akibat dari penjualan, tukar menukar, asuransi dan/atau pengadaan barang dan jasa termasuk penerimaan bunga, jasa giro atau penerimaan lain sebagai akibat penyimpanan dana pada bank serta penerimaan dari hasil penggunaan kekayaaan daerah yang tidak dipisahkan, merupakan PAD dan dalam hal daerah telah membentuk Badan Layanan Umum Daerah (BLUD) seperti Rumah Sakit Umum Daerah, maka penerimaan rumah sakit tersebut dicantumkan dalam APBD sebagai jenis pendapatan Lain-lain PAD Yang Sah.

\section{Dana Perimbangan}

Dalam rangka pelaksanaan desentralisasi penyelenggaraan pemerintahan daerah, kepada Daerah diberikan dana perimbangan melalui APBN yang bersifat transfer dengan prinsip money follows function. Salah satu tujuan pemberian dana perimbangan tersebut adalah untuk mengurangi k'esenjangan fiskal antara pemerintah dengan daerah dan antar daerah, serta meningkatkan kapasitas daerah dalam menggali potensi ekonomi daerah.

\section{Lain-Lain Pendapatan Daerah Yang Sah}

Pemerintah Kabupaten/Kota dalam menetapkan pendapatan bagi hasil yang diterirna dari provinsi pada Tahun Anggaran yang akan datang agar menggunakan pagu Tahun Anggaran sebelumnya dan pencantuman rencana penerimaan hibah berupa uang dalam APBD didasarkan atas Naskah Perjanjian Hibah (NPH) dan bagi daerah yang belum menganggarkan pendapatan yang bersumber dari dana alokasi umum, dana bagi hasil, hibah, dana darurat, dan sumbangan pihak ketiga pada Satuan Kerja Pengelola Keuangan Daerah (SKPKD) supaya dalam penyusunan APBD Tahun Anggaran tahun mendatang dianggarkan pada SKPKD.

\section{Karakteristik Value For Money}

Pengertian VFM dalam keuangan adalah suatu proses yang sistematis untuk memperoleh dan mengevaluasi bukti secara obyektif mengenai asersi atas tindakan dan kejadian ekonomi, kesesuaiannya dengan kriteria/standar yang telah ditetapkan dan 
kemudian mengkomunikasikan hasilnya kepada pihak-pihak pengguna laporan tersebut. (Malan, 2010).

VFM kinerja memfokuskan pemeriksaan pada tindakan-tindakan dan kejadiankejadian ekonomi yang menggambarkan kinerja entitas atau fungsi. Definisi kinerja adalah suatu proses sistematis untuk memperoleh dan mengevaluasi bukti secara obyektif, agar dapat melakukan penilaian secara independen atas ekonomi dan efesiensi operasi, efektivitas dalam pencapaian hasil yang diinginkan, dan kepatuhan terhadap kebijakan, peraturan dan hukum yang berlaku, menentukan kesesuaian antara kinerja yang telah dicapai dengan kriteria yang telah ditetapkan sebelumnya, serta mengkomunikasikan hasilnya pada pihak-pihak pengguna laporan tersebut. (Malan, 2010).

Kinerja suatu organisasi dinilai baik jika organisasi yang bersangkutan mampu melaksanakan tugas-tugas dalam rangka mencapai tujuan yang telah ditetapkan pada standar yang tinggi dengan biaya yang rendah. Secara teknis kinerja yang baik bagi suatu organisasi dicapai ketika administrasi dan penyediaan jasa oleh organisasi yang bersangkutan dilakukan pada tingkat yang ekonomis, efisien dan efektif. Konsep ekonomi, efisien dan efektivitas saling berhubungan satu sama lain dan tidak dapat diartikan/dimaknai secara terpisah atau sendiri-sendiri. Konsep ekonomi memastikan bahwa biaya input yang digunakan dalam dalam operasional organisasi dapat diminimalkan, konsep efisiensi memastikan bahwa output yang maksimal dapat dicapai dengan sumber daya yang tersedia, konsep efektif berarti bahwa jasa yang disediakan/dihasilkan oleh organisasi dapat melayani kebutuhan pengguna jasa dengan tepat.

\section{Ekonomi dan Efisiensi}

Ekonomi mempunyai arti biaya terendah, sedangkan efisiensi mengacu pada rasio terbaik antara output dengan biaya (input). Karena output dan biaya diukur dalam unit yang berbeda maka efisiensi dapat terwujud ketika dengan sumberdaya yang ada dapat dicapai output yang maksimal atau output tertentu dapat dicapai dengan sumberdaya yang sekecil-kecilnya.

Ekonomi dan efisiensi bertujuan untuk menentukan :

1 .Apakah suatu entitas telah memperoleh, melindungi dan menggunakan sumber dayanya (seperti: karyawan, gedung, ruang, dan peraltan kantor) secara ekonomis dan efisien.

2. Penyebab terjadinya praktis-praktis yang tidak ekonomis atau tidak efisien, termasuk ketidakmampuan organisasi dengan mengelola sistem informasi, prosedur administrasi dan struktur organisasi.

Prosedur untuk melakukan ekonomi dan efisiensi sama dengan jenis lainnya. Secara umum, tahapan-tahapan yang dilakukan meliputi :

1. Perencanaan

2. Me- review sistem akuntansi dan pengendalian interen

3. Menguji sitem akuntansi dan pengendalian interen

4. Melaksanakan

5. Menyampaikan laporan

Efektivitas

Efektivitas berkaitan dengan pencapain tujuan. Menurut Comission (2010), efektivitas berarti menyediakan jasa-jasa yang benar sehingga memungkinkan pihak yang berwenang untuk mengimplementasikan kebijakan dan tujuannya. Efektivitas (program) bertujuan untuk menetukan:

1. Tingkat pencapaian hasil atau manfaat yang diinginkan 
2. Kesesuaian hasil dengan tujuan yang ditetapkan sebelumnya

3. Apakah entitas yang diaudit telah mempertimbangkan alternatif lain yang memberikan hasil yang sama dengan biaya yang paling rendah.

Efektivitas berkenaan dengan dampak suatu output bagi pengguna jasa (konsumen). Untuk mengukur efektivitas suatu kegiatan harus didasarkan pada kriteria yang telah ditetapkan (disetujui) sebelumnya. Jika hal ini belum tersedia, bekerja sama dengan top management dan badan pembuat keputusan untuk menghasilkan kriteria tersebut dengan berpedoman pada tujuan pelaksanaan suatu program.

Seperti telah dijelaskan sebelumnya, bahwa kinerja pada dasarnya merupakan perluasan dari keuangan dalam hal tujuan dan prosedurnya. Pada kinerja, kegiatan pemeriksaan terhadap pengelolaan organisasi sektor publik terutama didasarkan pada tiga elemen utama yaitu: ekonomi, efisiensi dan efektivitas. Penekanan kegiatan pada ekonomi, efisiensi dan efektivitas suatu organisasi memberikan ciri khusus yang membedakan kinerja dengan jenis lainnya

\section{Standar Audit Pemerintahan (SAP)}

Audit kinerja dalam lembaga pemerintahan di Indonesia dilakukan dengan berpedoman pada Standar Audit Pemerintahan (SAP) yang dikeluarkan oleh Badan Pemeriksaan Keuangan (BPK). SAP tersebut merupakan buku standar untuk melakukan audit atas semua kegiatan pemerinyah yang meliputi pelaksanaan APBN, APBD, pelaksanaan anggaran tahunan BUMN dan BUMD, serta kegiatan yayasan yang didirikan oleh pemerintah, BUMN dan BUMD atau badan hukum lain yang didalamnya terdapat kepentingamn keuangan negara atau yang menerima bantuan pemerintah.

\section{METODE PENELITIAN}

\section{Jenis Data Penelitian}

Penelitian ini menggunakan data kuantitatif sebagai satu-satunya jenis data. Data kuantitatif adalah data yang dinyatakan dalam bentuk angka, dapat diukur, dan dilakukan perhitungan serta perlu ditafsirkan terlebih dahulu agar menjadi suatu informasi. Data yang digunakan didalam penelitian ini adalah data sekunder, yaitu data yang telah ada dari dokumen resmi pemerintah daerah kota Malang. Data sekunder ini terdiri atas : Laporan Realisasi Anggaran kota Malang serta data pendukung lainnya yang bersumber dari Publikasi DJPK Kemenkeu, data statistik kota Malang, data dari BPKAD (Badan Pengelolaan Keuangan dan Aset Daerah) kota Malang serta data realisasi pendapatan daerah kota Malang dari dinas pendapatan kota Malang. Selain itu informasi pendukung berasal dari hasil wawancara dengan staf bagian akuntansi BPKAD (Badan Pengelolaan Keuangan dan Aset Daerah) Kota.

\section{Lokasi Penelitian}

Penelitian ini dilakukan pada pemerintah kota Malang dengan pengambilan data yang dilakukan pada Dinas Pendapatan Daerah Kota Malang, Bappeda Kota Malang dan Bappeda dan BPKAD Kota Malang sebagai pengelola keuangan pemerintah kota Malang. BPKAD kota Malang berlokasi di Jalan Tugu No 1 Kota Malang. Sedangkan Dispenda kota Malang berlokasi di perkantoran terpadu kota Malang Gedung B Jalan Mayjen Sungkono Kota Malang.

\section{Data dan Jenis Data}

Penelitian ini menggunakan data kuantitatif sebagai satu-satunya jenis data. Data kuantitatif adalah data yang dinyatakan dalam bentuk angka, dapat diukur, dan dilakukan perhitungan serta perlu ditafsirkan terlebih dahulu agar menjadi suatu informasi. Data yang digunakan didalam penelitian ini adalah data sekunder, yaitu data 
yang telah ada dari dokumen resmi pemerintah daerah kota Malang. Data sekunder ini terdiri atas : Laporan Realisasi Anggaran kota Malang serta data pendukung lainnya yang bersumber dari Publikasi DJPK Kemenkeu, data statistik kota Malang, data dari BPKAD (Badan Pengelolaan Keuangan dan Aset Daerah) kota Malang serta data realisasi pendapatan daerah kota Malang dari dinas pendapatan kota Malang. Selain itu informasi pendukung berasal dari hasil wawancara dengan staf bagian akuntansi BPKAD (Badan Pengelolaan Keuangan dan Aset Daerah) Kota.

\section{Teknik Pengumpulan Data}

Teknik pengumpulan data yang dilakukan peneliti adalah dengan cara Logging data, yaitu saat pengumpulan data. Pada tahapan terakhir ini proses mengumpulkan data penelitian yang diperlukan, Teknik ini dilakukan dengan Malang. memberikan perrtanyaan terbuka dan mengarah pada kedalaman infromasi serta dilakukan tidak secara formal dan terstruktur guna menggali pandangan dan informasi dari obyek yang diteliti dari informan tersebut. Informan pada penelitian ini adalah Staff Bagian Akuntansi dan bendahara pengeluaran BPKAD kota Malang.

\section{Teknik Analisis Data}

Setelah data-data tersebut diperoleh, selanjutnya dianalisis dengan menggunakan analisis deskriptif (Nazir, 2008:63), yaitu suatu metode dalam meneliti suatu objek dengan cara membuat suatu gambaran secara sistematis, faktual dan akurat mengenai fakta-fakta serta hubungan antar fenomena yang diselidiki.

\section{PEMBAHASAN}

\section{Tingkat Efektivitas APBD}

Berdasarkan hasil perhitungan dalam tabel 4.1. di atas memang tingkat efektivitas APBD sangat efektif. Namun demikian, yang perlu dicermati adalah apakah efektivitas APBD tersebut sudah OPTIMAL?. Jangan-jangan APBD yang sangat efektif tersebut hanya efektif yang semu. Karena, selama ini pihak eksekutif maupun legislatif dalam menyusun APBD tidak memperhatikan data potensi tahun mendatang, namun belanja tahun berikutnya dihitung dengan meningkatkan sejumlah peroentase tertentu dari tahun-tahun sebelumnya (biasanya sebesar tingkat inflasi untuk tahun berikutnya). Di samping itu, penilaian keberhasilan APBD sebagai penilaian pertanggung jawaban pengelolaan keuangan daerah lebih ditekankan pada pencapaian target, kurang memperhatikan bagaimana perubahan yang terjadi pada komposisi dan struktur APBDnya yang dapat mempengaruhi rasio-rasio keuangannya. Ini berdampak pada kurang efisiennya tingkat APBD.

\section{Tingkat Efisiensi APBD}

Berdasarkan hasil perhitungan dalam tabel 4.2 di atas, tampak bahwa tingkat efisiensi APBD yang masih kurang efisien, hal ini disebabkan karena belanja daerah menunjukkan lebih besar dari pendapatan daerah, sehingga hasilnya selalu melebihi 80 persen. Ke depan pendapatan daerah perlu dioptimalkan, terutama PAD, sehingga dapat melebihi belanja daerah yang pada akhirnya hasilnya kurang dari 80 persen.

Selama ini pengelolaan keuangan daerah masih sangat memprihatinkan. Anggaran daerah, khususnya pengeluaran daerah belum mampu berperan sebagai insentif dalam mendorong laju pembangunan. Di sisi lain banyak ditemukan pengalokasian anggaran yang tidak sesuai dengan kebutuhan dan peruntukannya/penggunaannya tidak dilakukan secara prudent (hati-hati), sehingga kurang mencerminkan aspek efisiensi. Hal ini disebabkan karena kualitas perencanaan anggaran daerah relatif lemah. Perencanaan anggaran yang lemah juga diikuti dengan ketidakmampuan pemerintah daerah untuk meningkatkan penerimaan daerah secara 
berkesinambungan. Selanjutnya, suatu anggaran yang telah direncanakan dengan baik, hendaknya disertai pula dengan pelaksanaan yang tertib dan disiplin, sehingga baik tujuan maupun sasaran akan dapat tercapai secara berdayaguna dan berhasilguna dan mencerminkan kemampuan pengelolaan keuangan yang baik.

\section{Tingkat Kemampuan Keuangan Daerah}

Tingkat kemampuan keuangan daerah berdasarkan hasil perhitungan menunjukkan kurang mampu/rendah sekali, karena hasilnya selalu dibawah dari kriteria yang ditentukan Ini berarti pendapatan daerah Kota Malang sebagian besar berasal di luar PAD. Berdasarkan uraian di atas, agar di masa mendatang kemampuan keuangan daerah Kota Malang dapat meningkat, maka perlu dilakukan analisis potensi PAD. Potensi PAD adalah kekuatan yang ada di suatu daerah untuk menghasilkan sejumlah penerimaan PAD. Untuk mengetahui potensi sumber-sumber PAD dibutuhkan pengetahuan tentang analisis perkembangan beberapa variabel yang dapat dikendalikan, yaitu variabel kebijakan dan kelembagaan, dan dan tidak dapat dikendalikan, yaitu variabel-variabel ekonomi yang dapat mempengaruhi kekuatan sumber-sumber penerimaan PAD.

Upaya meningkatkan PAD melalui pajak ataupun retribusi daerah akan berhasil bila pemerintah daerah menunjukkan itikad yang sungguh-sungguh untuk meningkatkan pelayanan publiknya. Peningkatan pelayanan publik ini tercermin dengan meningkatnya proporsi belanja langsung, yaitu belanja yang dikeluarkan oleh pemerintah daerah yang bersinggungan langsung dengan kegiatan masyarakat.

Seiring dengan meningkatnya PAD, diharapkan tingkat kemandirian pemerintah daerah semakin meningkat. Tingkat kemandirian ini ditunjukkan dengan kontribusi PAD untuk mendanai belanja-belanja daerahnya. Ketergantungan pemerintah daerah terhadap pemerintah pusat harus semakin kecil (Sidik, 2002).

Dalam upaya meningkatkan PAD Pemkot Malang di masa medatang, maka pihak Pemkot Malang perlu mengetahui variabel-variabel potensial yang dapat mempengaruhi PAD (Simanjuntak dalam Halim 2004:92-106), yaitu:

1. Kondisi Awal Suatu Daerah. Kondisi struktur ekonomi dan sosial daerah sangatlah menentukan. Pada masyarakat agraris, pemerintah tidak akan terpacu untuk menarik pungutan-pungutan dari masyarakat. Sementara dalam masyarakat industri pemerintah akan terpacu untuk menarik pungutan-pungutan untuk memenuhi tuntutan akan ketersediaan fasilitas pelayanan publik. Karena perbedaan pada struktur ekonomi dan sosialnya, kemampuan membayar segala pungutan yang ditetapkan oleh pemerintah daerah akan lebih tinggi di masyarakat industri daripada masyarakat agraris.

2. Peningkatan Cakupan atau Ekstensifikasi dan Intensifikasi Penerimaan PAD. Kegiatan ini merupakan upaya memperluas cakupan penerimaan PAD. Ada 3 hal penting yang harus diperhatikan dalam usaha peningkatan cakupan ini, yaitu: (a) menambah objek dan subjek dan atau retribusi, (b) meningkatkan besarnya penetapan, dan (c) mengurangi tunggakan.

3. Perkembangan PDRB Per Kapita Riil. Semakin tinggi pendapatan seseorang maka akan semakin tinggi pula kemampuan seseorang untuk membayar (ability to pay) berbagai pungutan yang ditetapkan oleh pemerintah. Dengan logika yang sama, semakin tinggi PDRB (Produk Domestik Regional Bruto) per kapita riil suatu daerah, maka semakin besar pula kemampuan masyarakat daerah tersebut untuk membiayai pengeluaran rutin dan pengeluaran pembangunan daerahnya.

4. Pertumbuhan Penduduk. Besarnya pendapatan dapat dipengaruhi oleh jumlah penduduk. Jika jumlah penduduk meningkat, maka pendapatan yang dapat ditarik akan 
meningkat. Tetapi pertumbuhan penduduk mungkin tidak mempengaruhi pertumbuhan pendapatan secara proporsional.

5. Tingkat Inflasi. Inflasi akan meningkatkan penerimaan PAD yang penetapannya didasarkan pada omzet penjualan, misalnya pajak hotel dan pajak restoran. Untuk pajak atau retribusi yang penetapannya didasarkan pada tarif tetap, maka inflasi diperlukan dalam pertimbangan perubahan tarif.

6. Penyesuaian Tarif. Peningkatan pendapatan sangat tergantung pada kebijakan penyesuaian tarif. Untuk pajak atau retribusi yang tarifnya ditentukan secara tetap, maka dalam penyesuaian tarif perlu mempertimbangkan laju inflasi. Kegagalan untuk menyesuaikan tarif dengan laju inflasi akan menghambat peningkatan PAD. Dalam rangka penyesuaian tarif retribusi, selain harus memperhatikan laju inflasi, perlu juga ditinjau hubungan antara biaya pelayanan jasa dengan penerimaan PAD.

1. Pembangunan Baru. Peningkatan PAD juga dapat diperoleh bila pembangunanpembangunan baru ada, seperti pembangunan ruko, pembangunan pasar, pembangunan sub terimal, dan lain-lain.

Sumber Pendapatan Baru. Adanya kegiatan usaha baru dapat mengakibatkan bertambahnya sumber pendapatan pajak atau retribusi yang sudah ada. Misalnya, usaha persewaan VCD, usaha persewaan komputer/warnet/wartel, dan lain-lain.

2. Perubahan Peraturan. Adanya peraturan-peraturan baru, khususnya yang berhubungan dengan pajak dan atau retribusi, akan dapat meningkatkan PAD. Pajak daerah dan retribusi daerah merupakan salah satu bentuk peran serta masyarakat dalam penyelenggaraan otonomi daerah.

3. Pajak daerah dan retribusi daerah merupakan sumber pendapatan daerah yang penting untuk membiayai penyelenggaraan pemerintahan dan pembangunan daerah. Permasalahan yang dihadapi oleh daerah pada umumnya dalam kaitan penggalian sumber-sumber pajak daerah dan retribusi daerah, yang merupakan salah satu komponen dari PAD, adalah belum memberikan kontribusi yang signifikan terhadap penerimaan daerah secara keseluruhan.

Di samping hal di atas, perlu juga diperhatikan oleh pihak Pemkot Malang bahwa tidak sedikit permasalahan yang terjadi di daerah berkaitan dengan penggalian dan peningkatan PAD. Permasalahan tersebut menurut Sidik (2002:144-149) muncul disebabkan oleh beberapa hal sebagai berikut:

1. Relatif rendahnya basis pajak dan retribusi daerah. Berdasarkan UU No.34 tahun 2000 daerah Kabupaten/Kota dimungkinkan untuk menetapkan jenis pajak dan retribusi baru. Namun, melihat kriteria pengadaan pajak baru sangat ketat, khususnya kriteria pajak daerah tidak boleh tumpang tindih dengan Pajak Pusat dan Pajak Propinsi, diperkirakan daerah memiliki basis pungutan yang relatif rendah dan terbatas, serta sifatnya bervariasi antar daerah. Rendahnya basis pajak ini bagi sementara daerah berarti memperkecil kemampuan manuver keuangan daerah dalam menghadapi krisis ekonomi.

2. Perannya yang tergolong kecil dalam total penerimaan daerah. Sebagian besar penerimaan daerah masih berasal dari bantuan Pusat. Dari segi upaya pemungutan pajak, banyaknya bantuan dan subsidi ini mengurangi "usaha" daerah dalam pemungutan PAD-nya, dan lebih mengandalkan kemampuan "negosiasi" daerah terhadap Pusat untuk memperoleh tambahan bantuan.

3. Kemampuan administrasi pemungutan di daerah yang masih rendah. Hal ini mengakibatkan bahwa pemungutan pajak cenderung dibebani oleh biaya pungut yang besar. PAD masih tergolong memiliki tingkat buoyancy yang rendah. Salah satu sebabnya adalah diterapkan sistem "target" dalam pungutan daerah. Sebagai 
akibatnya, beberapa daerah lebih condong memenuhi target tersebut, walaupun dari sisi pertumbuhan ekonomi sebenarnya pemasukkan pajak dan retribusi daerah dapat melampaui target yang ditetapkan.

4. Kemampuan perencanaan dan pengawasan keuangan yang lemah. Hal ini mengakibatkan kebocoran-kebocoran yang sangat berarti bagi daerah. Selama ini, peranan PAD dalam membiayai kebutuhan pengeluaran daerah sangat kecil dan bervariasi antar daerah yaitu kurang dari 10\% hingga 50\%. Sebagian besar daerah Propinsi hanya dapat membiayai kebutuhan pengeluarannya kurang dari 10\% Variasi dalam penerimaan ini diperparah lagi dengan sistem bagi hasil (bagi hasil didasarkan pada daerah penghasil sehingga hanya menguntungkan daerah tertentu). Demikian pula, distribusi pajak antar daerah juga sangat timpang karena basis pajak antar daerah sangat bervariasi . Peranan pajak dan retribusi daerah dalam pembiayaan yang sangat rendah dan bervariasi juga terjadi karena adanya perbedaan yang sangat besar dalam jumlah penduduk, keadaan geografis (berdampak pada biaya yang relatif mahal), dan kemampuan masyarakat, sehingga mengakibatkan biaya penyediaan pelayanan kepada masyarakat sangat bervariasi.

\section{DAFTAR PUSTAKA}

Amirrullah, dan R. Hanafi. 2012. Pengantar Manajemen. Cetakan 1. Graha Ilmu. Yogyakarta

Arfan. 2010. http://arfanhy.blogspot.com. Diakses Februari 2013

Bastian, I. 2010. Akuntansi Sektor Publik: Suatu Pengantar. Penerbit Erlangga. Jakarta

Baswir, R. 2010. Akuntansi Pemerintahan Indonesia. BPFE. Yogyakrta

Darise, N. 2011. Pengelolaan Keuangan Daerah. Indeks Kelompok Gramedia. Jakarta

Devas, N., B. Bender, A. Booth, K. Davey, dan R. Kelly. 2011. Keuangan Pemerintah Daerah di Indonesia. Diterjemahkan oleh Masri Maris. UI-Press. Jakarta

Devas, Nick. 2010. Financing Local Government in Indonesia, Planning and Administration (Asia $\mathcal{E}$ Pasific Special). IULA. Ohio University.

Dewi. 2009. http://dewi.students-blog.undip.ac.id/tag/efektivitas. Diakses Februari 2013

Faisal, S. 2012. Format-format Penelitian Sosial: Dasar-dasar dan Aplikasi. Rajawali Pers. Jakarta.

Halim, A. 2010. Manajemen Keuangan Daerah. Edisi Revisi. UPP AMP YKPN. Yogyakarta

Halim, A. dan J. A. Nasir. Kajian tentang Keuangan Daerah Pemerintah Kota Malang. Usahawan. No. 06 TH XXXV Juni 2013. Lembaga Management FE-UI. Jakarta

Handoko. T. H. 2011. Organisasi Perusahaan, Teori, Struktur dan Perilaku. BPFE. Yogyakarta

Jones, B. 2013. Financial Management In The Public Sector. Mc-Graw Hill Companies. England. Edisi Bahasa Indonesia. Salemba Empat. Jakarta

Kaho, J. R. 2010. Prospek Otonomi Daerah di Negara Republik Indonesia. Raja Grafindo Persada. Jakarta

Kristiadi, J. B. 2011. Masalah Sekitar Pendapatan Daerah. Prisma. tahun XIV. LP3ES. Jakarta. 
Evi Indana Ulfa, Analisis Kinerja APBD Dengan Pengukuran Value For Money Pemerintah Kota Malang (Tahun Periode 2011-2015)

Mamesah. 2010. Sistem Administrasi Keuangan Daerah. PT. Gramedia Pustaka Utama. Jakarta

Mardiasmo, 2011. Akuntansi Sektor Publik. Penerbit Andy. Yogyakarta.

Martoyo. 2014. http://komengpoenya.blogspot.com. Diakses Februari 2013

Munir, D., H. A. Djuanda, dan H. N. Sangkilisan. 2011. Kebijakan dan Manajemen Keuangan Daerah. YPAI. Yogyakarta

Nazir, M. 2010. Metode Penelitian. Ghalia Indonesia. Jakarta

Puspitosari, H. 2011. Marginalisasi Rakyat dalam Anggaran Publik, Partisipasi Rakyat dalam Menyusun Anggaran Publik di Daerah. MCW dan Yappika. Malang

Rejo, Ibnu. 2014. Intensifikasi dan Ekstensifikasi Peningkatan PAD. Mimeo. Makalah pada Seminar Ototnomi Dati II. Bangkinang. Riau.

Sidik, M. 2014. http://www.djpk.depkeu.go.id. Diakses Mei 2013

Suadi, A. 2014. Penelitian tentang Manfaat Laporan Arus Kas. Jurnal Ekonomi dan Bisnis. Vol 13. N0. 32. UGM. Yogyakarta

Sugiyono. 2011. Metode Penelitian Bisnis. Alfabeta. Bandung

Sidik, M. 2014. http://www.djpk.depkeu.go.id. Diakses Februari 2013

Steers. 2015. http://komengpoenya.blogspot.com. Diakses Februari 2013

Sumardi. 2015. http://www.docstoc.com/docs/4957489/ PAD dan Peta Kemampuan Keuangan Daerah. Diakses Februari 2013

Tambunan, B. S. 2014. Perimbangan Keuangan Pusat dan Daerah. Bina Rena Parawira. Jakarta.

Tjokroamidjojo, Bintoro. 2014. Pengantar Administrasi Pembangunan. LP3ES. Jakarta.

Yuliati. 2015. http://one.indoskripsi.com. Diakses Februari 2013 